Black Is a Country 



\section{Black Is a Country}

Race and the Unfinished Struggle for Democracy

NIKHIL PAL SINGH

HARVARD UNIVERSITY PRESS

Cambridge, Massachusetts, and London, England 2004 
Copyright $\odot 2004$ by the President and Fellows of Harvard College All rights reserved

Printed in the United States of America

Library of Congress Cataloging-in-Publication Data

Singh, Nikhil Pal.

Black is a country : race and the unfinished struggle for democracy / Nikhil Pal Singh. p. $\mathrm{cm}$.

Includes bibliographical references and index.

ISBN 0-674-01300-X (alk. paper)

1. African Americans-Civil rights-History-20th century.

2. African Americans-Politics and government-20th century.

3. Democracy-United States-History-20th century.

4. Racism-Political aspects-United States-History-20th century.

5. United States-Politics and government-20th century.

6. United States-Race relations-Political aspects. I. Title.

E185.61.S6144 2004

$323.173-\mathrm{dc} 22 \quad 2003067740$ 
The worlds within and without the Veil of Color are changing, and changing rapidly, but not at the same rate, not in the same way; and this must produce a peculiar wrenching of the soul, a peculiar sense of doubt and bewilderment. Such a double life, with double thoughts, double duties, and double social classes, must give rise to double words and double ideals, and tempt the mind to pretense or to revolt, to hypocrisy or to radicalism.

-W. E. B. DU BOIS, THE SOULS OF BLACK FOLK

The history of subaltern social groups is necessarily fragmented and episodic. There undoubtedly does exist a tendency to (at least provisional stages of) unification in the historical activity of these groups, but this tendency is continually interrupted by the activity of the ruling groups; it therefore can only be demonstrated when an historical cycle is completed and this cycle culminates in a success ... only "permanent" victory breaks their subordination.

-ANTONIO GRAMSCI, SELECTIONS FROM THE PRISON NOTEBOOKS

"Black" is a country.

-LEROI JONES, HOME: SOCIAL ESSAYS 
